\title{
Nematode communities in greenhouse soil of different ages from Shenyang suburb
}

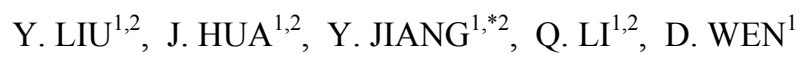 \\ ${ }^{1}$ Key Laboratory of Terrestrial Ecological Process, Institute of Applied Ecology, Chinese Academy of Sciences, \\ Shenyang 110016, China; ${ }^{2}$ Graduate School of the Chinese Academy of Sciences, Beijing 100039, China; \\ E-mail: jiangyong@iae.ac.cn
}

\begin{abstract}
Summary
The distribution of nematode communities with depth in greenhouse soil of different ages from Shenyang suburb was investigated in October 2004. Thirteen families and 23 genera were observed in our study. Heterocephalobus was dominant genus in all treatments. The numbers of total nematodes and trophic groups declined with soil depth but increased with greenhouse age. Bacterivores were the most abundant trophic group in all treatments, followed by plant parasites and omnivores-predators, while fungivores were the least, only accounted for less than $4 \%$ of the total abundance. Maturity index (MI) and plant parasite index (PPI) were effective in distinguishing differences in nematode community structure in different ages of greenhouses. The numbers of total nematodes were positively correlated with soil organic carbon, total nitrogen, nitrate, and electrolytic conductivity, but negatively with soil $\mathrm{pH}$.
\end{abstract}

Key words: greenhouse soil; nematode community; trophic group; maturity index; vertical distribution

\section{Introduction}

Knowledge of spatial patterns of nematodes contributes to better understanding of below-ground fauna community structure and functioning (Lazarova et al., 2004). It has been shown that nematode communities exhibit a typical vertical distribution, which often relates to a variety of biological, physical and chemical variables of soils (Ou et al., 2005). Gradual reductions of nematode abundance and diversity, and changes in the distribution of trophic group composition have been observed with increasing soil depth (Lazarova et al., 2004).

Vegetable plantation in greenhouse soil is a major way of vegetable production during winter in North China. Soil properties in greenhouses are changed significantly by excessive use of organic (compost and chicken manure) and synthetic fertilizers (mainly $\mathrm{N}$ fertilizer), intensive mana- gement, and by the environment of high temperature and moisture content (Jiang et al., 2003; Li et al., 2004). In greenhouses, the amount of soil organic matter and total nitrogen were increased, the soil physiochemical properties of soil degradation and the salt was accumulated (Jiang et al., 2003; Jiao et al., 2003). Changes in soil properties could have directly or indirectly influences on vertical distribution of nematode communities, whereas the changes in soil nematode communities at a vertical scale are very important in interpreting the impact of soil environmental change on soil processes and assessing its sustainability. There is no information on the vertical distribution of nematode communities in Chinese greenhouse soil of differrent ages at present. The objectives of this study were to describe the vertical distribution of nematode communities in greenhouse soil of different ages, and to determine the relationships between soil chemical properties and nematode communities in greenhouse conditions.

\section{Material and Methods}

This study was conducted at Damintun town $\left(41^{\circ} 50^{\prime} \mathrm{N}\right.$, $122^{\circ} 55^{\prime} \mathrm{E}$ ), Shenyang municipality, Liaoning province, China in October 2004. Three kinds of greenhouses of different ages were selected with similar management way, each greenhouse was about 0.1 ha. The previous vegetable planted in the greenhouses was tomato (Lycopersicon esculentum Mill.). The soil at the study site is meadow soil (Hapli-Udic Cambosols in Chinese Soil Taxonomy) (CRG CST, 2001). The three treatments were: 1-year greenhouse (C1), 4-year greenhouse (C2), and 10-year greenhouse (C3). Greenhouse soil was amended with synthetic fertilizer $\left(4000 \mathrm{~kg} \mathrm{ha}^{-1}\right)$ and chicken manure $\left(80\right.$ t.ha $\left.^{-1}\right)$ each year.

Soil samples were taken from each greenhouse at the depths of $0-10 \mathrm{~cm}, 10-20 \mathrm{~cm}$ and $20-30 \mathrm{~cm}$ with 4 replications. Soil moisture was determined gravimetrically by 
drying samples at $105^{\circ} \mathrm{C}$ for $24 \mathrm{~h}$ and expressed as g. $\mathrm{kg}^{-1}$ (Liang et al., 2005a). Nematodes were extracted from 100 $\mathrm{g}$ (fresh weight) of soil from each sample using sugar flotation and centrifugation, and nematode populations were expressed per $100 \mathrm{~g}$ dry weight soil (Ou et al., 2005). After counting the number of total nematodes, 100 nematodes per sample were selected randomly and identified to genus (Liang et al., 2005b). The classification of trophic groups was assigned to: (1) bacterivores, (2) fungivores, (3) plant parasites, and (4) omnivores-predators based on known feeding habits or stoma and esophageal morphology (Yeates \& Bongers, 1999; Liang et al., 2001; Liang et al., 2005a). Within each trophic group, nematodes were ranked by life strategy according to Bongers (1990) and Renčo (2004). The two indices relating to the nematode fauna were calculated: (1) the maturity index (MI), which was calculated across all nematode genera except plant parasites $\mathrm{MI}=\Sigma v_{i} \bullet p_{i}$, where $v_{i}$ is the $c$ - $p$ value of the $i$ th genus, and $p_{i}$ is the proportion of the $i$ th genus in the nematode community, using $c-p$ values from 1 to 5 as defined by Bongers (1990) to reflect a relative degree of colonization or persistence of the genus; (2) the plant parasite index (PPI), which was determined in a similar manner for plant parasitic genera (Bongers 1990).

Soil total organic carbon (TOC) was analyzed by dry combustion using TOC 5000 (Shimadzu, Kyoto) analyzer (Liang et al., 2005b); total nitrogen was determined by Kjeldahl digestion, followed by $\mathrm{NaOH}$ distillation, and measured by titration with $25 \mathrm{mmol} . \mathrm{I}^{-1} \mathrm{H}_{2} \mathrm{SO}_{4}$ in boric acid indicator; nitrate and ammonium concentrations were determined by extraction with 2 mol. $\mathrm{l}^{-1} \mathrm{KCl}$, steam digestion, and titration; and soil salinity was determined in soil extracts and expressed as electrolytic conductivity (EC) (Page, 1982).

All the data were subjected to statistical analysis of variance (ANOVA). Differences with $\mathrm{P}<0.05$ were considered significant.

\section{Results}

The number of total nematodes ranged between 455 and 794 individuals per $100 \mathrm{~g}$ dry soil in different treatments, and increased with the ages of greenhouse but declined with soil depth. Significant differences were found among treatments and depths $(\mathrm{P}<0.01)$.

Thirteen families and 23 genera were observed in the greenhouses soil (Tab. 1). Heterocephalobus was found to be dominant genus in all treatments, which relative abundances were $63.4 \%(\mathrm{C} 1), 59.7 \%(\mathrm{C} 2)$ and $66.4 \%(\mathrm{C} 3)$, respectively. Helicotylenchus and Pratylenchus were dominant genera in four-year $(17.4 \%)$ and ten-year greenhouses $(12.8 \%)$, respectively. The number of genera declined with soil depths in one-year greenhouse, and the similar numbers of genera were found in four-year and ten-year greenhouses.

The most nematode genera belonged to the populations of plant parasites (12), followed by bacterivores (5) and omnivore-predators (4), only two genera were found belonging to fungivores. Bacterivorous nematodes were the most dominant trophic group in all treatments, followed by plant parasitic nematodes; fungivores and omnivore-predators were rare and both no more than $5 \%$. The numbers of bacterivores, fungivores, and plant-parasites increased with the ages of greenhouse. Significant differences among treatments were found in the numbers of bacterivores $(\mathrm{P}<$ $0.05)$, fungivores $(\mathrm{P}<0.01)$ and plant parasites $(\mathrm{P}<0.01)$. The numbers of omnivore-predators were highest in the treatment of four-year greenhouse, and least in ten-year greenhouse. Significant differences were observed in the numbers of omnivore-predators among the three treatments $(\mathrm{P}<0.01)$. The numbers of bacterivores, fungivores, plant parasites and omnivores- predators decreased with soil depth in all treatments. The density gradient in different soil depth declined gradually with the increasing of greenhouse age (Fig. 1). The number of total nematodes, bacteri-

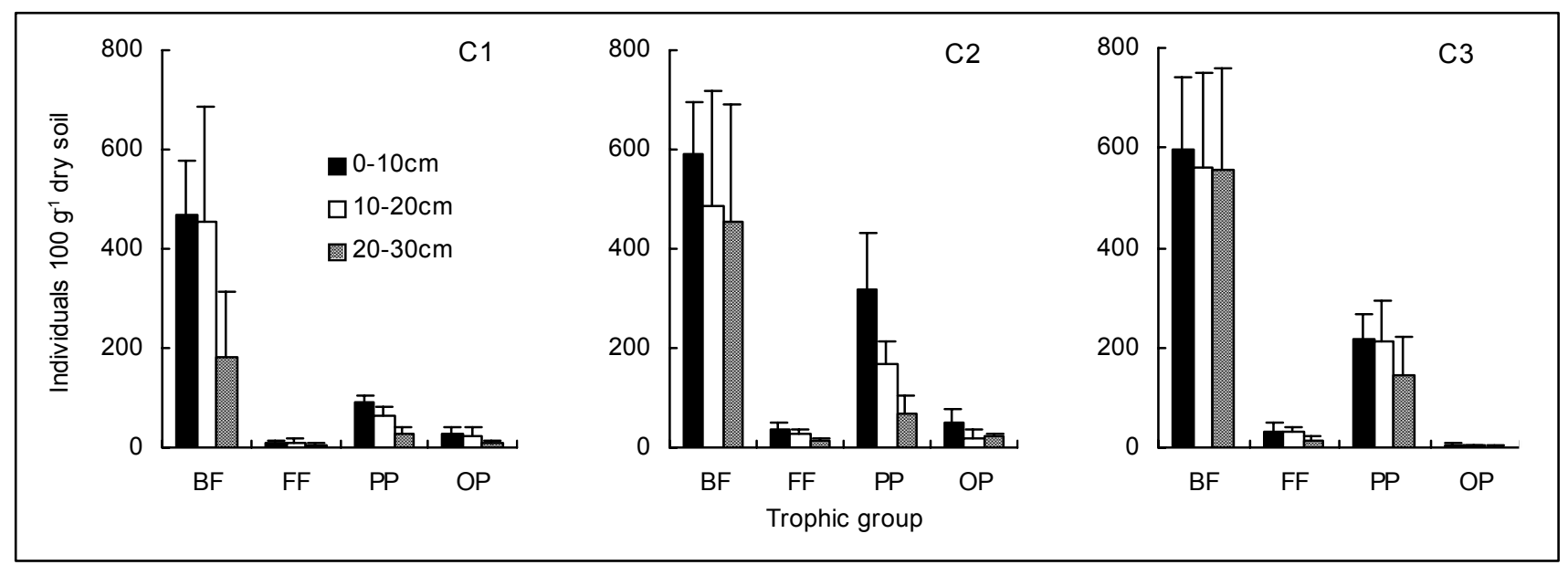

Fig.1 Vertical distribution of nematode trophic groups under greenhouse soil of different ages

$\mathrm{BF}, \mathrm{FF}, \mathrm{PP}$, and OP are bacterivores, fungivores, plant-parasites, and omnivore-predators, respectively. C1 - one year greenhouse; $\mathrm{C} 2$ - four year greenhouse; $\mathrm{C} 3$ - ten year greenhouse 
Tab. 1. Nematode genera and families identified in greenhouse soils

\begin{tabular}{|c|c|c|c|}
\hline Trophic group & Family & Genera & $c-p$ \\
\hline \multirow[t]{5}{*}{ Bacterivores } & Cephalobidae & Acrobeles & 2 \\
\hline & & Acrobeloides & 2 \\
\hline & & Eucephalobus & 2 \\
\hline & & Heterocephalobus & 2 \\
\hline & Monhysteridae & Eumonhystera & 2 \\
\hline \multirow[t]{2}{*}{ Fungivores } & Aphelenchidae & Aphelenchus & 2 \\
\hline & Aphelenchoididae & Aphelenchoides & 2 \\
\hline \multirow[t]{12}{*}{ Plant-parasites } & Tylenchidae & Filenchus & 2 \\
\hline & & Malenchus & 2 \\
\hline & & Tylenchus & 2 \\
\hline & Dolichodoridae & Scutylenchus & 3 \\
\hline & Pratylenchidae & Hoplotylus & 3 \\
\hline & & Pratylenchus & 3 \\
\hline & & Pratylenchoides & 3 \\
\hline & Nordiidae & Longidorella & 4 \\
\hline & Hoplolaimidae & Helicotylenchus & 3 \\
\hline & & Rotylenchus & 3 \\
\hline & Criconematidae & Macroposthonia & 3 \\
\hline & Psilenchidae & Psilenchus & 2 \\
\hline \multirow[t]{4}{*}{ Omnivore-predators } & Qudsianematidae & Epidorylaimus & 4 \\
\hline & & Eudorylaimus & 4 \\
\hline & & Thonus & 4 \\
\hline & Nygolaimidae & Nygolaimus & 5 \\
\hline
\end{tabular}

$\mathrm{c}-\mathrm{p}$ values for nematode genera or families were based on Bongers (1990) and Yeates and Bongers (1999)

vores, fungivores and plant parasites were correlated positively with soil total organic carbon, total nitrogen, nitrate and soil electrolytic conductivity, but negatively with soil $\mathrm{pH}$ (Tab. 2).

The values of MI decreased and the PPI increased with the increasing of greenhouse age, and no significant differen- ces were found in the values of MI and PPI at different soil depths (Tab. 3). MI values were correlated negatively with soil total organic carbon, total nitrogen, nitrate and electrolytic conductivity, but positively with soil $\mathrm{pH}$. PPI values were correlated positively with soil organic carbon and negatively with soil $\mathrm{pH}$ (Tab. 2).

Table 2. Correlation coefficients for soil nematodes and soil chemical properties in greenhouse soils

\begin{tabular}{lcccrrr}
\hline Indicator & $\mathrm{TOC}$ & $\mathrm{EC}$ & $\mathrm{pH}$ & $\mathrm{Total} \mathrm{N}$ & $\mathrm{NH}_{4}{ }^{+}-\mathrm{N}$ & $\mathrm{NO}_{3}{ }^{-}-\mathrm{N}$ \\
\hline Total nematodes & $0.604^{* *}$ & $0.363^{*}$ & $-0.497^{* *}$ & $0.502^{* *}$ & 0.190 & $0.402^{*}$ \\
Bacterivores & $0.432^{* *}$ & $0.332^{*}$ & $-0.415^{*}$ & $0.396^{*}$ & 0.271 & $0.354^{*}$ \\
Fungivores & $0.549^{* *}$ & $0.329^{*}$ & $-0.451^{* *}$ & $0.464^{* *}$ & $-0.370^{*}$ & $0.436^{* *}$ \\
Plant-parasites & $0.565^{* *}$ & 0.235 & $-0.473^{* *}$ & $0.424^{* *}$ & 0.046 & 0.291 \\
Omnivore-predators & -0.064 & -0.164 & 0.123 & -0.253 & -0.097 & -0.043 \\
Maturity index & $-0.354^{*}$ & $-0.342^{*}$ & $0.458^{* *}$ & $-0.513^{* *}$ & -0.258 & -0.222 \\
Plant parasite index & $0.487^{* *}$ & $0.426^{* *}$ & $-0.538^{* *}$ & $0.529^{* *}$ & 0.236 & $0.426^{* *}$ \\
\hline
\end{tabular}

Explanations: TOC - soil total organic carbon; EC - soil electrolytic conductivity; Total N - soil total nitrogen

*,** - Correlations are significant at the 0.05 and 0.01 levels, respectively

Table 3. Maturity indices of soil nematodes under three treatments

\begin{tabular}{|c|c|c|c|c|c|c|}
\hline \multirow[t]{2}{*}{ Depth } & \multicolumn{3}{|c|}{ Maturity index (MI) } & \multicolumn{3}{|c|}{ Plant parasite index (PPI) } \\
\hline & $\mathrm{C} 1$ & $\mathrm{C} 2$ & C3 & $\mathrm{C} 1$ & $\mathrm{C} 2$ & $\mathrm{C} 3$ \\
\hline $0-10 \mathrm{~cm}$ & $2.11 \pm 0.08$ & $2.11 \pm 0.04$ & $2.02 \pm 0.02$ & $2.73 \pm 0.21$ & $2.94 \pm 0.03$ & $2.95 \pm 0.04$ \\
\hline $10-20 \mathrm{~cm}$ & $2.10 \pm 0.04$ & $2.08 \pm 0.06$ & $2.01 \pm 0.00$ & $2.54 \pm 0.26$ & $2.80 \pm 0.09$ & $2.95 \pm 0.08$ \\
\hline $20-30 \mathrm{~cm}$ & $2.12 \pm 0.04$ & $2.10 \pm 0.04$ & $2.01 \pm 0.04$ & $2.49 \pm 0.25$ & $2.66 \pm 0.16$ & $3.02 \pm 0.02$ \\
\hline
\end{tabular}

Explanations: $\mathrm{C} 1$ - one year greenhouse; $\mathrm{C} 2$ - four year greenhouse; $\mathrm{C} 3$ - ten year greenhouse 


\section{Discussion}

In this study, bacterivorous and plant parasitic nematodes were more abundant trophic groups present in greenhouse soil of different ages. Populations of the both trophic groups increased with the increasing of planting-year in greenhouses. Neher (1999) also found the similar result that bacterivorous and plant-parasitic nematodes were the most abundant trophic groups in organically and conventionally managed soils and the numbers of the both trophic groups were greater in soils managed organically than conventionally. These results contrast with the reports that numbers of plant parasitic nematodes decreased after additions of organic amendments (Clark et al., 1998). Some studies showed that the effect of any amendments on plantparasitic nematode populations was unpredictable, although there was general agreement that organic amendments supply nutrients to plants and improve crop yields, the effect on nematodes could vary with the nematode species, type of amendment and its by-products, and length of time after application, and also depend on whether the experiments were conducted in the greenhouse, in microplots, or in the field (McSorley et al., 1997).

The numbers of total nematodes and trophic groups exhibited a gradual decrease trend with soil depth under different land use patterns (Ou et al. 2005). Yeates and Stannard (1983) also found that the total nematode population in $0-90 \mathrm{~cm}$ soil layers under cocksfoot swards declined consistently with soil depth. In this study, the similar results were observed that the numbers of total nematodes and trophic groups declined with soil depth. The differences in vertical distribution of the different feeding groups of nematodes were to some extent caused by differences in vertical distribution of their food sources (Ferris \& Mc Kenry, 1976).

The soil nematode community was sensitive to a gradient of changes in the soil environment. Some indices tested could be used to detect habitats affected by human intervention. The MI and PPI showed differences across treatments, systems and crops (Freckman \& Ettema, 1993). The maturity index (MI), a measure based on the composition of the nematode community, could reflect the degree of disturbance of the soil ecosystem (Bongers, 1990; Bongers et al., 1997). In this study, MI declined with the increasing of planting year in greenhouse, whereas the PPI increased with the increasing of planting year in greenhouse. Bongers et al. (1997) and Liang et al. (2005a) reported the inverse relationship between the MI and PPI under enriched nutrient conditions, e.g. the MI decreases and PPI increases with increasing nutrient status. This study also showed an inverse relationship between the MI and PPI.

Soil chemical properties are important relative to occurrence and population dynamics of nematodes. Soil $\mathrm{pH}$ was found significantly correlated with nematode numbers and might be used as a tool to predict where the nematodes are apt to occur (Norton \& Hoffmann, 1974). Norton et al. (1971) observed that all significant correlations of nema- tode numbers and soil $\mathrm{pH}$ were negative, except with Helicotylenchus, which were positive. This study also got the same result that soil $\mathrm{pH}$ was negatively correlated with nematode numbers. Soil pH is important, although probably indirectly, for nematode activity (Burns, 1971). It is generally recognized that soil $\mathrm{pH}$ can influence nematode development indirectly, through host reactions and by altering the chemical composition of soil or the antagonistic organisms present (Sarah et al., 1991). The values of soil electrolytic conductivity in our study exhibited significantly positive effects on the total nematodes, bacterivores and fungivores. The positive correlations were also found between bacterivores, fungivores and electrolytic conductivity in a desert ecosystem (Liang \& Steinberger, 2001). In summary, the numbers of total nematodes, bacterivores, fungivores and plant-parasites increased with the greenhouse ages and decreased with soil depths. The dynamics of the soil nematodes population are closely related with soil chemical properties. This research could indicate the health of greenhouse soil and might contribute to the control of soil-borne diseases.

\section{Acknowledgements}

This research was supported by the National Natural Science Foundation of China (No. 30570337). The authors thank Prof. Wenju Liang (Institute of Applied Ecology, Chinese Academy of Sciences) for his valuable comments and corrections of this manuscript.

\section{References}

Bongers, T. (1990): The maturity index: An ecological measure of environmental disturbance based on nematode species composition. Oecologia, 83: $14-19$

Bongers, T., Meulen, H., Korthals, G. (1997): Inverse relationship between the nematode maturity index and plant parasite index under enriched nutrient conditions. Appl. Soil Ecol., 6: 195 - 199

BuRNS, N. C. (1971): Soil pH effects on nematode populations associated with soybean. J. Nematol., 3: $238-245$

Clark, M. S., Ferris, H., Klonsky, K., LANINI, W. T., VAn Bruggen, A. H. C., Zalom, F. G. (1998): Agronomic, economic, and environmental comparison of pest management in conventional and alternative tomato and corn systems in northern California. Agric. Ecosyst. Environ., 68: $51-71$

CRGCST (Cooperative Research Group on Chinese Soil Taxonomy) (2001): Chinese Soil Taxonomy. Science Press, Beijng and New York

FERRIS, H., MCKENRY, M. V. (1976): Nematode community structure in a vineyard soil. J. Nematol. , 8: $131-137$

Freckman, D. W., EtTemA, C. H. (1993): Assessing nematode communities in agroecosystems of varying human intervention. Agric. Ecosyst. Environ. , 45: $239-261$

JiAnG, Y, ZhANG, Y. G., CHEN, L. J. (2003): Status of fertilizer input and it's influence on the qualities of farm produce and environment in Shenyang, China. In Ji, L. Z., 
Chen, G. X., Schnug, E. (Eds): Fertilizer, Food Security and Environmental Protection-Fertilizer in the Third Millennium-12 $2^{\text {th }}$ World Fertilizer Congress. Liaoning Science and Technology Publishing House, Shenyang, China. pp $515-523$

JiAO, K., LI, D. C. (2003): Changes in soil properties and environment in vegetable greenhouses. Soil (in Chinese), 2: $94-97$

Lazarova, S. S., De Goede, R. G. M., Peneva, V. K., BONGERS, T. (2004): Spatial patterns of variation in the composition and structure of nematode communities in relation to different microhabitats: a case study of Quercus dalechampii Ten forest. Soil Biol. Biochem., 36: 710 - 712 Li, G., Zhang, N. M., MaO, K. M., Shi, J., She, L. N. (2004): Characteristics of soil salt accumulation in plastic greenhouse and its control measures. Trans. CSAE (in Chinese), 20: $44-47$

Liang, W. J., Lavian, I., Pen-Mouratov, S., SteinberGER, Y. (2005a): Diversity and dynamics of soil free-living nematode populations in a Mediterranean agroecosystem. Pedosphere., 33: $208-213$

Liang, W. J., Li, Q., JiAng, Y., NeHER, D. A. (2005b): Nematode faunal analysis in an aquic brown soil fertilised with slow-release urea, Northeast China. Appl. Soil Ecol., 29: $185-192$

LiAng, W. J., Steinberger, Y. (2001): Temporal changes in nematode community structure in a desert ecosystem. $J$. Arid Environ., 48: 267 - 280

Mcsorley, R., Stansly, P. A., Noling, J. W., Oberza, T. A., CONNER, J. M. (1997): Impact of organic soil amen- dments and fumigation on plant-parasitic nematodes in asouthwest Florida vegetable field. Nematropica, 27: $181-$ 189

NEHER, D. A. (1999): Nematode communities in organically and conventionally managed agricultural soils. J. Nematol., $31: 142-154$

Norton, D. C., Frerick, L. R., Ponchillia, P. E., NYHAN, J. W. (1971): Correlations of nematodes and soil properties in soybean fields. J. Nematol., 3: $154-163$

Norton, D. C., Hoffmann, J. K. (1974): Distribution of selected plant parasitic nematodes relative to vegetation and edaphic factors. J. Nematol., 6: $81-86$

Ou, W., Liang, W. J., Jiang, Y., Li, Q., Wen, D. Z. (2005): Vertical distribution of soil nematodes under different land use types in an aquic brown soil. Pedobiologia, 49: $139-148$

Page, A. L. (1982): Methods of Soil Analysis Part 2: Chemical and Microbiological Properties ( $2^{\text {nd }}$ Eds). ASASSSA, Madison, Wisconsin

RENČO, M. (2004): Communities of nematodes in cereal fields following sugar beet. Helminthologia, 41: $109-122$

SARAH, J. L., OSSENI, B., HuGON, R. (1991): Effect of soil $\mathrm{pH}$ development of Pratylenchus brachyurus populations in pineapple roots. Nematropica, 21: $211-216$

YeAtes, G. W., Bongers, T. (1999): Nematode diversity in agroecosystems. Agric. Ecosyst. Environ., 74: 113 - 135 YeAtes, G. W., StanNARD, R. E. (1983): Vertical distribution of nematode populations in Horotiu soils. N. Z. Soil Bureau Sci. Rep., 60: 1 - 14 